\title{
Electrophoretic Analysis of Isoenzymes of Acholeplasma Species
}

\author{
M. M. SALIH, ${ }^{1 *}$ VIBEKE SIMONSEN ${ }^{2}$ AND H. ERN $\emptyset^{1}$ \\ Institute of Medical Microbiology ${ }^{1}$ and Institute of Ecology and Genetics, ${ }^{2}$ University of Aarhus, DK-8000 \\ Aarhus C, Denmark
}

\begin{abstract}
Thirteen Acholeplasma strains representing three named species, Acholeplasma laidlawii, Acholeplasma granularum, and Acholeplasma oculi, were examined for the presence of 30 enzymes by horizontal starch gel electrophoresis. A total of 29 enzymes were demonstrated. Twelve of these enzymes have not been reported previously in acholeplasmas (alcohol dehydrogenase, aldolase, alkaline phosphatase, arginase, arginine deiminase, carbamyl phosphokinase, galactose dehydrogenase, galactose-6-phosphate dehydrogenase, glutamate dehydrogenase [nicotinamide adenine dinucleotide], glutamate dehydrogenase [nicotinamide adenine dinucleotide phosphate], $\alpha$-glycerophosphate dehydrogenase, and xanthine dehydrogenase). An average group cluster analysis was carried out on the basis of estimates of dissimilarity coefficients. This analysis distinguished among the strains tested, was of some help in identification, and may also be useful in epidemiological investigations.
\end{abstract}

In the past, serology has been a cornerstone of Acholeplasma taxonomy. Some of the membrane-associated lipoglycans from different Acholeplasma species share antigenic determinants (20). Consequently, methods based on surface antigens, like growth inhibition and immunofluorescence tests, may not be reliable for definitive identification of acholeplasmas. The growth precipitation test appears to be almost species specific within the genus Acholeplasma, as cross-reactions seldom occur between recognized species $(8,14)$. In an exploratory study, Lanham et al. (17) found that isoenzyme analysis by (thin-layer) electrophoresis is useful for distinguishing between Acholeplasma laidlawii and Acholeplasma equifetale, as well for demonstrating intraspecific variation. The value of isoenzyme analysis in mycoplasma taxonomy received further substantial support from a study by O'Brien et al. (24).

The purpose of this study was to characterize and differentiate the type strains and a few field strains of three Acholeplasma species, $A$. laidlawii, Acholeplasma granularum, and Acholeplasma oculi, by analyzing soluble isoenzymes. These organisms have been reported to cross-react in growth inhibition and immunofluorescence tests and cannot be differentiated by any of the common biochemical tests.

\section{MATERIAL AND METHODS}

Acholeplasma strains. The following 13 strains were included in this study: the type strains of $A$. laidlawii (strain PG8 [sewage strain A]), A. granularum (strain
BTS-39), and A. oculi (strain 19-L), A. laidlawii strain PG9 (sewage strain B), and 9 strains isolated from bovine, caprine, ovine, equine, and avian sources. We attempted to classify these strains before isoenzyme analysis by the agar well modification of the growth inhibition test (4), the indirect epi-immunofluorescence technique (25), and the growth precipitation test (8). All cultures were filtered through a membrane filter (pore size, $450 \mathrm{~nm}$; Millipore Corp., Bedford, Mass.) and cloned on solid media by picking single colonies. This procedure was repeated three times. Cultures were selected for this study because crossreactions occurred to a higher degree than usual for a group of nine strains. Furthermore, the strains were isolated from different animal species and different geographic areas.

Cultivation and harvest of organisms. The growth medium used was essentially that of Lanham et al. (17). PPLO broth (Difco Laboratories, Detroit, Mich.) was supplemented with a $25 \%$ aqueous extract of dried yeast $(10 \%$, vol/vol), PPLO serum fraction $(1 \%$, vol/ vol; Difco), sodium deoxyribonucleate $(0.002 \%$, $\mathrm{wt} / \mathrm{vol})$, glucose $(0.5 \%$, wt/vol), phenol red $(0.002 \%$, $w / / v o l)$, and ampicillin $(300 \mathrm{mg} / \mathrm{ml})$, and the $\mathrm{pH}$ was adjusted to 7.8. In preliminary experiments this medium was compared with the same medium without glucose. Each strain was grown at $37^{\circ} \mathrm{C}$ in 1 to 1.6 liters of liquid medium. When the $\mathrm{pH}$ had fallen to 7.2 to 7.3 , the titer of the culture was recorded, either by determining the number of colony-forming units per milliliter or by cell counting after staining with acridine orange (26). Cultures were harvested by centrifugation at $8,000 \times \mathrm{g}$ for $30 \mathrm{~min}$ at $4^{\circ} \mathrm{C}$, and this was followed by washing twice in $0.25 \mathrm{M} \mathrm{NaCl}$ buffered to $\mathrm{pH} 7.0$ with $\mathrm{Na}_{2} \mathrm{HPO}_{4}$.

Preparation of culture lysates. After washing, the deposit was suspended in $12 \mathrm{ml}$ of an enzyme-stabilizing solution containing $1 \mathrm{mM}$ dithiothreitol, 1 
TABLE 1. Comparison of the immunofluorescence, growth inhibition, and growth precipitation tests for classification of Acholeplasma field strains

\begin{tabular}{|c|c|c|c|c|c|c|c|c|c|c|c|}
\hline \multirow{3}{*}{ Strain } & \multirow{3}{*}{ Source } & \multirow{3}{*}{$\begin{array}{l}\text { Phospha- } \\
\text { tase } \\
\text { activity }\end{array}$} & \multicolumn{9}{|c|}{ Results with the following antisera: } \\
\hline & & & \multicolumn{3}{|c|}{ IMF test $^{a}$} & \multicolumn{3}{|c|}{ GI test ${ }^{a}$} & \multicolumn{3}{|c|}{ GP test ${ }^{a}$} \\
\hline & & & $\mathrm{PG8}^{\mathrm{T}}$ & BTS-39 & $19-\mathrm{L}^{\mathrm{T}}$ & $\mathrm{PG8}^{\mathrm{T}}$ & BTS-39 & $19-\mathrm{L}^{\mathrm{T}}$ & $\mathrm{PG8}^{\mathrm{T}}$ & BTS- $39^{\mathrm{T}}$ & $19-\mathrm{L}^{\mathrm{T}}$ \\
\hline A. laidlawii $\mathrm{PG8}^{\mathrm{T}}$ & Sewage & $t^{b}$ & + & 0 & + & + & 0 & 0 & + & + & + \\
\hline $\begin{array}{l}\text { A. laidlawii (or A. } \\
\text { oculi?) T-OR (= } \\
\text { AMRC-C 380) }\end{array}$ & Cow & + & + & 0 & + & + & 0 & + & + & + & + \\
\hline A. laidlawii PG9 & Sewage & + & + & 0 & + & + & + & + & + & + & $\mathbf{0}$ \\
\hline $\begin{array}{l}\text { A. laidlawii } 60 \mathrm{~S} / 106(= \\
\text { AMRC-C 1374) }\end{array}$ & Goat & 0 & + & 0 & + & + & 0 & 0 & + & 0 & 0 \\
\hline $\begin{array}{l}\text { A. laidlawii HRV (= } \\
\text { AMRC-C 1453) }\end{array}$ & Bird & 0 & + & 0 & + & + & 0 & 0 & + & 0 & 0 \\
\hline $\begin{array}{l}\text { A. laidlawii AMRC-C } \\
1200 \text { (= Mycoplasma } \\
\text { 343) }\end{array}$ & Sheep & 0 & + & 0 & + & + & 0 & 0 & + & 0 & 0 \\
\hline $\begin{array}{l}\text { A. laidlawii L4297 (= } \\
\text { AMRC-C 1365) }\end{array}$ & Cow & 0 & + & 0 & + & + & 0 & + & + & 0 & 0 \\
\hline $\begin{array}{l}\text { A. laidlawii G20 (= } \\
\text { AMRC-C 750) }\end{array}$ & Goat & 0 & + & 0 & + & + & 0 & 0 & + & 0 & 0 \\
\hline $\begin{array}{l}\text { A. laidlawii D2753/188 } \\
\text { (= AMRC-C 1178) }\end{array}$ & Horse & 0 & + & + & + & + & 0 & 0 & + & 0 & 0 \\
\hline $\begin{array}{l}\text { A. laidlawii (?) J201/3 } \\
\text { (= AMRC-C 1119) }\end{array}$ & Cow & 0 & + & 0 & 0 & + & + & + & \pm & \pm & \pm \\
\hline $\begin{array}{l}\text { A. granularum BTS- } \\
39^{\mathrm{T}}\end{array}$ & Swine & 0 & 0 & + & 0 & 0 & + & 0 & 0 & + & 0 \\
\hline A. oculi $19-\mathrm{L}^{\mathrm{T}}$ & Goat & 0 & + & 0 & + & $\mathbf{0}$ & $\mathbf{0}$ & + & 0 & $\mathbf{0}$ & + \\
\hline $\begin{array}{l}\text { A. oculi G122 (= } \\
\text { AMRC-C 780) }\end{array}$ & Goat & 0 & $\mathbf{0}$ & 0 & + & + & 0 & + & 0 & 0 & + \\
\hline
\end{tabular}

a IMF, Immunofluorescence; GI, growth inhibition; GP, growth precipitation.

$b+$, Positive; 0 , negative; \pm , not positive all of the time.

$\mathrm{mM} \varepsilon$-aminocaproic acid, and $1 \mathrm{mM}$ ethylenediaminetetraacetate ( $\mathrm{pH} \mathrm{7.0)} \mathrm{(16).} \mathrm{Cell} \mathrm{lysates} \mathrm{were} \mathrm{prepared}$ as described by Lanham et al. (17); i.e., the suspension was frozen by using dry ice and acetone, and after thawing in lukewarm water the lysate was centrifuged at $100,000 \times g$ for $2 \mathrm{~h}$ to remove the cell membranes. The supernatant was concentrated with a Minicon model A25 multipurpose microconcentrator (Amicon, High Wycombe, England) and kept at $-70^{\circ} \mathrm{C}$ until it was used. No appreciable loss of enzyme activity occurred during storage under these conditions.

Isoenzyme electrophoresis. Horizontal starch gel electrophoresis was carried out as described by Hjorth (15). The following enzymes were assayed: acid phosphatase (EC 3.1.3.2), adenosine deaminase (EC 3.5.4.4), adenylate kinase (EC 2.7.4.3), alcohol dehydrogenase (EC 1.1.1.1), aldolase (EC 4.1.2.13), alkaline phosphatase (EC 3.1.3.1), arginase (EC 3.5.3.1), arginine deiminase (EC 3.5.3.6), aspartate aminotransferase (EC 2.6.1.1), carbamyl phosphokinase (EC 2.7.2.2), esterase (EC 3.1.1.1), galactose dehydrogenase (EC 1.1.1.48), galactose-6-phosphate dehydrogenase, glucose-6-phosphate dehydrogenase (EC 1.1.1.49), glucose phosphate isomerase (EC 5.3.1.9), glutamate dehydrogenase (nicotinamide adenine dinucleotide) (EC 1.4.1.2), glutamate dehydrogenase (nicotinamide adenine dinucleotide phosphate) (EC 1.4.1.4), $\alpha$-glycerophosphate dehydrogenase (EC 1.1.1.8), hexokinase (EC 2.7.1.1), inorganic pyrophosphatase (EC 3.6.1.1), lactate dehydrogenase (EC
1.1.1.27), malate dehydrogenase (EC 1.1.1.37), mannose phosphate isomerase (EC 5.3.1.8), nucleoside phosphorylase (purine) (EC 2.4.2.1), ornithine transcarbamylase (EC 2.1.3.3), 6-phosphogluconate dehydrogenase (EC 1.1.1.44), phosphoglucomutase (EC 2.7.5.1), phosphoglycerate kinase (EC 2.7.2.3), superoxide dismutase (EC 1.15.1.1), and xanthine dehydrogenase (EC 1.2.1.37). The buffers used for acid phosphatase, alkaline phosphatase, arginase, arginine deiminase, carbamyl phosphokinase, galactose dehydrogenase, galactose-6-phosphate dehydrogenase, glucose phosphate isomerase, $\alpha$-glycerophosphate dehydrogenase, inorganic pyrophosphatase, mannose phosphate isomerase, phosphoglucomutase, superoxide dismutase, and xanthine dehydrogenase were those described by Spencer et al. (35); the buffers used for aldolase, adenylate kinase, esterase, galactose-6phosphate dehydrogenase, hexokinase, lactate dehydrogenase, 6-phosphogluconate dehydrogenase, phosphoglycerate kinase, and superoxide dismutase were those described by Carter (6); the buffers used for adenosine deaminase and alcohol dehydrogenase were those described by Smith (32); another buffer used for alcohol dehydrogenase was that described by Shaw (29); the buffers used for aspartate aminotransferase, glutamate dehydrogenase (nicotinamide adenine dinucleotide), glutamate dehydrogenase (nicotinamide adenine dinucleotide phosphate), and nucleoside phosphorylase (purine) were those described by Ashton and Braden (2); the buffers used for galactose dehy- 
TABLE 2. Positions of enzyme bands for 13 Acholeplasma strains ${ }^{a}$

\begin{tabular}{|c|c|c|c|c|c|c|c|c|c|c|c|}
\hline \multirow[b]{2}{*}{ Strain } & \multicolumn{11}{|c|}{ Enzyme bands identified } \\
\hline & $\underset{(4)^{b}}{\mathrm{ACP}}$ & $\begin{array}{c}\text { AK } \\
(4)\end{array}$ & $\underset{(3)}{A L D}$ & $\begin{array}{c}\text { ALP } \\
\text { (4) }\end{array}$ & $\begin{array}{c}\text { ARG } \\
(3)\end{array}$ & $\begin{array}{l}\text { ARDI } \\
(2)\end{array}$ & $\begin{array}{l}\text { ASAT } \\
\text { (3) }\end{array}$ & $\begin{array}{c}\text { CPK } \\
(3)\end{array}$ & EST (6) & $\underset{\text { (3) }}{\text { GA6PDH }}$ & $\begin{array}{l}\text { G6PDH } \\
\text { (4) }\end{array}$ \\
\hline $\begin{array}{l}\text { A. laidlawii } \mathrm{PG8}^{\mathrm{T}} \\
\text { AMRC-C } 380(=\mathrm{T} \text { - }\end{array}$ & $\mathrm{D}^{c}$ & A & $\mathrm{C}$ & B,D & $\mathrm{C}$ & A,B & B & $\mathrm{A}, \mathrm{B}$ & $\mathrm{D}, \mathrm{E}, \mathrm{F}$ & $\mathrm{C}$ & C,D \\
\hline OR) & $\mathrm{D}$ & A,B & B & B,D & $\mathrm{C}$ & A,B & $0^{d}$ & B & $\mathrm{D}, \mathrm{E}, \mathrm{F}$ & 0 & $\mathrm{C}, \mathrm{D}$ \\
\hline A. laidlawii PG9 & D & A & B & B,D & $\mathrm{C}$ & A,B & B & $\mathrm{A}, \mathrm{B}$ & $\mathrm{D}, \mathrm{E}, \mathrm{F}$ & $\mathrm{C}$ & C,D \\
\hline$\underset{106)}{\operatorname{AMRC}-C} 1374(=60 \mathrm{~S} /$ & D & A,B & $\mathrm{C}$ & B,D & $A, B$ & $\mathbf{B}$ & $\mathbf{B}$ & A & C,D,E & $\mathrm{C}$ & C,D \\
\hline $\begin{array}{l}\text { AMRC-C } 1453(= \\
\text { HRV) }\end{array}$ & A,D & $\mathrm{A}, \mathrm{B}$ & $\mathrm{C}$ & $\mathbf{B}$ & $A, B$ & $\mathbf{B}$ & B & A & C,D,E & $\mathbf{B}$ & C,D \\
\hline $\begin{array}{l}\text { AMRC-C } 1200(= \\
\text { Mycoplasma } 343)\end{array}$ & A,D & A,B & $\mathrm{C}$ & $A, D$ & $\mathbf{A}$ & A & B & A & $\mathrm{D}, \mathrm{E}, \mathrm{F}$ & B & C,D \\
\hline $\begin{array}{l}\text { AMRC-C } 1365(= \\
\text { L4297) }\end{array}$ & D & A & $\mathrm{C}$ & B,D & A,B & A,B & A & A & $\mathrm{C}, \mathrm{D}$ & $\mathrm{C}$ & C,D \\
\hline AMRC-C $750(=$ G20) & D & A & $\mathrm{C}$ & A,D & 0 & 0 & A & A & $\mathrm{D}$ & $\mathbf{B}$ & $\mathrm{C}$ \\
\hline $\begin{array}{l}\text { AMRC-C } 1178(= \\
\text { D2753/188) }\end{array}$ & A,D & $\mathbf{B}$ & $\mathrm{C}$ & D & 0 & 0 & 0 & 0 & E,F & $\mathrm{C}$ & D \\
\hline$\underset{3)}{\operatorname{AMRC}-C} 1119(=\mathrm{J} 201 /$ & $\mathrm{C}$ & $\mathrm{D}$ & $\mathbf{A}$ & B & A & A & $\mathrm{C}$ & 0 & $\mathrm{E}$ & A & $\mathrm{C}$ \\
\hline A. granularum BTS- & $\mathrm{B}, \mathrm{C}$ & A,D & $\mathrm{C}$ & A,C & 0 & 0 & $\mathbf{B}$ & A & $\mathrm{D}, \mathrm{E}, \mathrm{F}$ & $\mathrm{C}$ & $\mathrm{B}, \mathrm{C}$ \\
\hline A. oculi $19-\mathrm{L}^{\mathrm{T}}$ & A & C & $\mathbf{B}$ & A,C & $\mathbf{B}$ & B & $\mathbf{B}$ & $\mathbf{B}$ & $\mathbf{A}, \mathbf{B}, \mathbf{E}$ & $\mathbf{0}$ & A,B \\
\hline AMRC-C $780(=$ G122) & A & $\mathbf{B}$ & $\mathbf{B}$ & $\mathrm{B}, \mathrm{C}$ & A & 0 & 0 & A & $\mathrm{A}, \mathrm{E}$ & A & A,B \\
\hline
\end{tabular}

${ }^{a}$ Abbreviations: ACP, acid phosphatase; AK, adenylate kinase; ALD, aldolase; ALP, alkaline phosphatase; ARG, arginase; ARDI, arginine deiminase; ASAT, aspartate aminotransferase; CPK, carbamyl phosphokinase; EST, esterase; GA6PDH, galactose-6-phosphate dehydrogenase; G6PDH, glucose-6-phosphate dehydrogenase; GLUD (NAD), glutamate dehydrogenase (nicotinamide adenine dinucleotide); GLUD (NADP), glutamate dehydrogenase (nicotinamide adenine dinucleotide phosphate); $\alpha \mathrm{GPD}, \alpha$-glycerophosphate dehydrogenase; HK, hexokinase; LDH, lactate dehydrogenase; MPI, mannose phosphate isomerase; NP, nucleoside phosphorylase (purine); 6PGD, 6-phosphogluconate dehydrogenase; PGM, phosphoglucomutase; PGK, phosphoglycerate kinase; SOD, superoxide dismutase; XDH, xanthine dehydrogenase.

${ }^{b}$ The numbers in parentheses are numbers of electromorphs for each enzyme.

${ }^{c}$ In each case band $\mathrm{A}$ had the slowest migration rate, band $\mathrm{B}$ had the next slowest migration rate, etc.

${ }^{d} 0$, No enzyme present.

drogenase, glucose phosphate isomerase, mannose phosphate isomerase, and ornithine transcarbamylase were those described by Harris and Hopkinson (13); the buffer used for aspartate aminotransferase was that described by Godfrey and Kilgour (12); other buffers used for aspartate aminotransferase and galactose dehydrogenase were those described by Nelson et al. (23); and the buffer used for esterase was that described by Clayton and Tretiak (7). Acid phosphatase, alcohol dehydrogenase, aldolase, alkaline phosphatase, arginase, glutamate dehydrogenase (nicotinamide adenine dinucleotide), glutamate dehydrogenase (nicotinamide adenine dinucleotide phosphate), hexokinase, inorganic pyrophosphatase, mannose phosphate isomerase, nucleoside phosphorylase (purine), ornithine transcarbamylase, phosphoglucomutase, and phosphoglycerate kinase were stained by the methods of Harris and Hopkinson (13). The staining procedures used for the following enzymes have been described previously: adenosine deaminase (34), adenylate kinase (9), arginine deaminase (36), aspartate aminotransferase (27), carbamyl phosphokinase (31), esterase (30), galactose dehydrogenase (29), galactose6-phosphate dehydrogenase (29), glucose-6-phosphate dehydrogenase (11), 6-phosphogluconate dehydrog- enase (11), glucose phosphate isomerase (38), $\alpha$-glycerophosphate dehydrogenase (28), xanthine dehydrogenase (28), lactate dehydrogenase (10), malate dehydrogenase (10), and superoxide dismutase (3).

Estimation of dissimilarity coefficients. The theory for the method used to estimate dissimilarity coefficients has been described by Brewer (5) and elaborated on by Sneath and Sokal (33). We used a simplified modification of this method, which was described in detail by Wellendorf and Simonsen (37). To estimate dissimilarity coefficients, all bands or electromorphs were taken into consideration. We counted the number of identical electromorphs present in both strains (a), the identical electromorphs absent in both strains (b), the electromorphs absent in one strain but present in the other $(c)$, and vice versa $(d)$. The dissimilarity coefficient was defined as follows: $(c+d) /(a+b+c$ $+d)$. This value was then used in an unweighted pair group arithmetic clustering method to construct a dendrogram.

\section{RESULTS}

Identification of field strains by serology. Seven of the nine field strains examined could be 
TABLE 2-Continued

\begin{tabular}{|c|c|c|c|c|c|c|c|c|c|c|c|}
\hline \multicolumn{12}{|c|}{ Enzyme bands identified } \\
\hline $\begin{array}{l}\text { GLUD } \\
\text { (NAD) } \\
\text { (2) }\end{array}$ & $\begin{array}{l}\text { GLUD } \\
\text { (NADP) } \\
\text { (2) }\end{array}$ & $\underset{\text { (4) }}{\alpha \text { GPD }}$ & HK (5) & $\begin{array}{l}\text { LDH } \\
\text { (4) }\end{array}$ & $\begin{array}{l}\text { MPI } \\
\text { (2) }\end{array}$ & $\begin{array}{l}\text { NP } \\
\text { (3) }\end{array}$ & $\begin{array}{l}\text { 6PGD } \\
\text { (3) }\end{array}$ & $\begin{array}{c}\text { PGM } \\
\text { (6) }\end{array}$ & $\begin{array}{c}\text { PGK } \\
\text { (3) }\end{array}$ & $\begin{array}{l}\text { SOD } \\
\text { (2) }\end{array}$ & $\underset{(4)}{\text { XDH }}$ \\
\hline A & A & A,B,D & B & C & B & $\mathbf{A}$ & B & A & A,B & A & $A, D$ \\
\hline $\begin{array}{l}\text { A } \\
\mathbf{A} \\
\mathbf{A}\end{array}$ & $\begin{array}{l}\mathbf{A} \\
\mathbf{A} \\
\mathbf{A}\end{array}$ & $\begin{array}{c}\mathbf{A}, \mathbf{D} \\
\mathbf{A} \\
\mathbf{A}\end{array}$ & $\begin{array}{l}\text { A } \\
\text { A } \\
\text { B }\end{array}$ & $\begin{array}{c}\text { C } \\
\text { B } \\
\mathbf{B}, \mathbf{D}\end{array}$ & $\begin{array}{l}\text { B } \\
\text { B } \\
\text { A }\end{array}$ & $\begin{array}{c}\mathbf{A} \\
\mathbf{A}, \mathbf{B}\end{array}$ & $\begin{array}{l}\text { B } \\
\mathbf{B} \\
\mathbf{B}\end{array}$ & $\begin{array}{c}\text { A } \\
\text { A,B } \\
\text { B,C }\end{array}$ & $\begin{array}{c}\mathbf{A}, \mathbf{B} \\
\mathbf{A} \\
\mathbf{A}\end{array}$ & $\begin{array}{l}\mathbf{A} \\
\mathbf{A} \\
\mathbf{A}\end{array}$ & $\begin{array}{l}\text { A } \\
\text { B } \\
\text { A }\end{array}$ \\
\hline A & $\mathbf{A}, \mathbf{B}$ & A,D & B & C & A & A,B & B & $A, B$ & A & A & A,D \\
\hline $\mathbf{A}$ & $\mathbf{A}$ & B,C & B,C,D & B,C & A & A,B & $\mathbf{A}$ & B,C,D & A & $\mathrm{A}, \mathrm{B}$ & A \\
\hline B & B & A & $\mathrm{C}$ & D & A & A,B & $\mathbf{A}$ & B,C,D & B & B & A \\
\hline $\begin{array}{l}\text { B } \\
\text { A }\end{array}$ & $\begin{array}{l}\text { B } \\
\text { B }\end{array}$ & $\begin{array}{l}\mathrm{A} \\
\mathrm{C}\end{array}$ & $\begin{array}{l}\text { B } \\
\text { C }\end{array}$ & $\begin{array}{l}\text { A } \\
\text { D }\end{array}$ & $\begin{array}{l}0 \\
\text { B }\end{array}$ & $\begin{array}{l}\text { B } \\
\text { A }\end{array}$ & $\begin{array}{l}\mathrm{A} \\
\mathrm{C}\end{array}$ & $\underset{\mathrm{B}, \mathrm{C}}{\mathrm{A}}$ & $\begin{array}{l}\text { A } \\
\text { B }\end{array}$ & $\begin{array}{l}\text { A } \\
\text { A }\end{array}$ & $\begin{array}{l}A \\
C\end{array}$ \\
\hline$A$ & $\mathbf{A}$ & $\mathbf{A}$ & D & C & A & A & $\mathrm{B}, \mathrm{C}$ & E,F & A,B & B & A \\
\hline $\mathbf{A}, \mathbf{B}$ & A & $\mathrm{A}, \mathrm{C}$ & $\mathrm{D}, \mathrm{E}$ & $\mathrm{A}, \mathrm{C}$ & $A, B$ & B,C & $\mathrm{C}$ & $\mathrm{C}, \mathrm{D}, \mathrm{E}$ & A,B & B & $\mathrm{A}, \mathrm{C}$ \\
\hline $\begin{array}{l}\mathbf{A}, \mathbf{B} \\
\mathbf{A}, \mathbf{B}\end{array}$ & $\underset{\text { B }}{A, B}$ & $\begin{array}{c}\text { B,C } \\
\mathbf{A}, \mathbf{B}, \mathbf{C}\end{array}$ & $\begin{array}{l}\text { C,D } \\
\text { B,C }\end{array}$ & $\begin{array}{l}\text { D } \\
\text { B }\end{array}$ & $\begin{array}{l}\text { B } \\
\text { B }\end{array}$ & $\begin{array}{l}\text { A } \\
\text { B }\end{array}$ & $\underset{B}{A, B}$ & $\begin{array}{l}\mathrm{D}, \mathrm{E} \\
\mathrm{D}, \mathrm{E}\end{array}$ & $\begin{array}{l}\mathrm{C} \\
\mathrm{C}\end{array}$ & $\begin{array}{l}\mathbf{A} \\
\mathbf{A}\end{array}$ & $\begin{array}{l}\text { B,C } \\
\text { B,C }\end{array}$ \\
\hline
\end{tabular}

identified by evaluating the results of all three serological methods used (Table 1). Undiluted antisera were used in the growth inhibition and growth precipitation tests, whereas the indirect immunofluorescence test was performed with sera diluted 1:20. Six of the field strains were classified as $A$. laidlawii, whereas on the basis of immunofluorescence and growth precipitation tests strain AMRC-C 780 was similar to A. oculi. However, we observed a cross-reaction between this strain and $A$. laidlawii when the growth inhibition technique was used.

Strain AMRC-C 1119 could not be identified with certainty, although our results suggested a relationship to $A$. laidlawii. This strain may represent a fourth species and possessed nonspecies-specific surface antigens, as well as group-specific cytoplasmic antibodies, in common with $A$. laidlawii.

Strain AMRC-C 380 could equally well be classified as $A$. laidlawii or $A$. oculi, since it was positive in all three tests with antisera against these two species.

Isoenzyme survey. A total of 13 strains were examined for the presence of 30 enzymes. Ornithine transcarbamylase was not demonstrated in any of these strains.

Because of the activity of other esterases or because of indistinct bands, distinct electromorphs were not observed for the following enzymes: adenosine deaminase, alcohol dehydrogenase, galactose phosphate dehydrogenase, malate dehydrogenase, and inorganic pyrophosphatase. Clear bands of glucose phosphate isom- erase were not obtained, but this enzyme expressed a very high activity.

Table 2 shows the positions of bands of 23 enzymes for all 13 strains examined.

On the basis of the results shown in Table 2, dissimilarity coefficients were estimated by the method described above (Table 3). The unweighted pair group arithmetic clustering method was used, and the resulting dendrogram is shown in Fig. 1.

It appears from Table 2 that it was not possible to identify the strains by the presence or absence of any enzyme, because of infrasubspecific variation and because some strains expressed some enzymes very weakly.

The dissimilarity coefficient offers a quantitative measure for the relationship between two strains. The dissimilarity coefficients for type strains PG8 and BTS-39, PG8 and 19-L, and BTS-39 and 19-L were $0.46,0.56$, and 0.54 , respectively. Strain AMRC-C 1119 was unrelated to the type strains of $A$. oculi, $A$. laidlawii and A. granularum (dissimilarity coefficients 0.56 , 0.41 , and 0.38 , respectively).

\section{DISCUSSION}

In general, our results are in accordance with the results obtained by other workers (17-19, 24). However, O'Brien et al. (24) did not detect mannose phosphate isomerase or inorganic pyrophosphatase. With respect to malate dehydrogenase, our results differ from those of Lanham et al. (17); however, although we did 


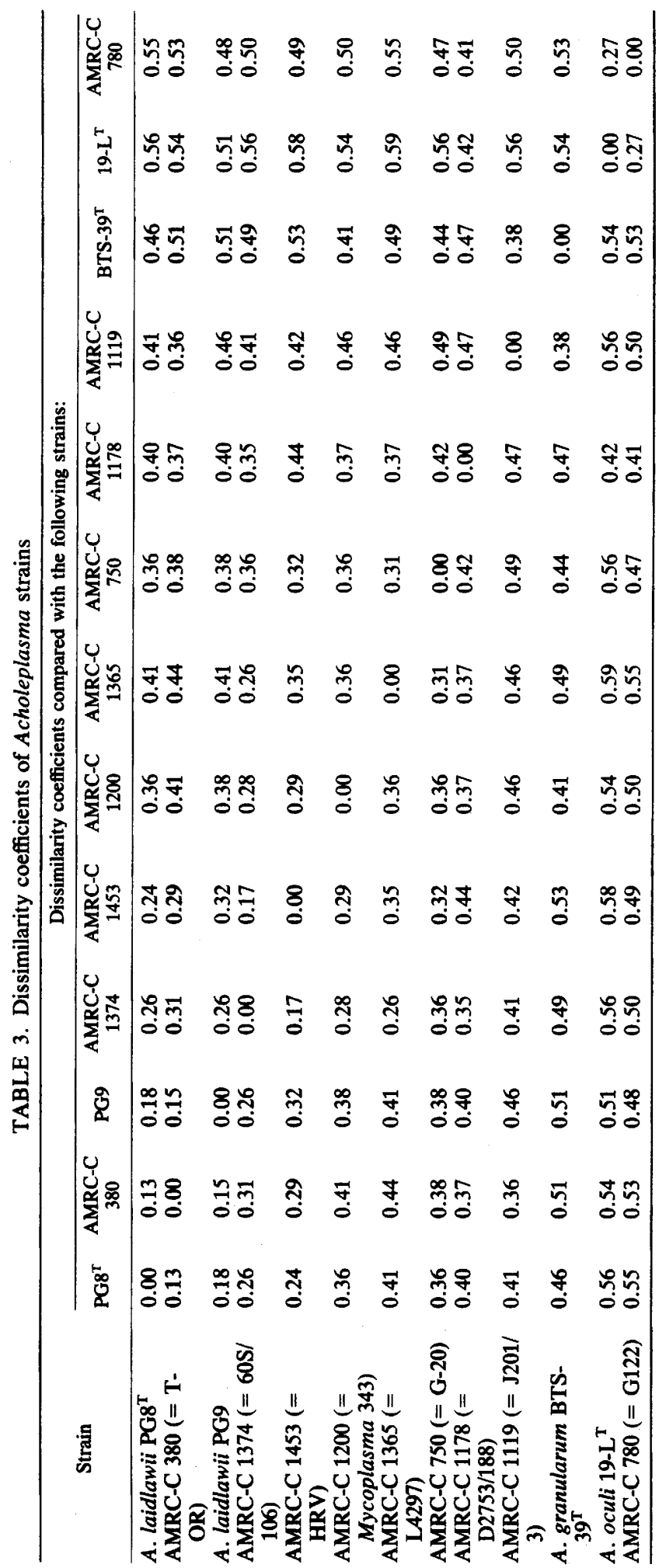




\subsection{0 .500 .400 .300 .200 .100 .00}

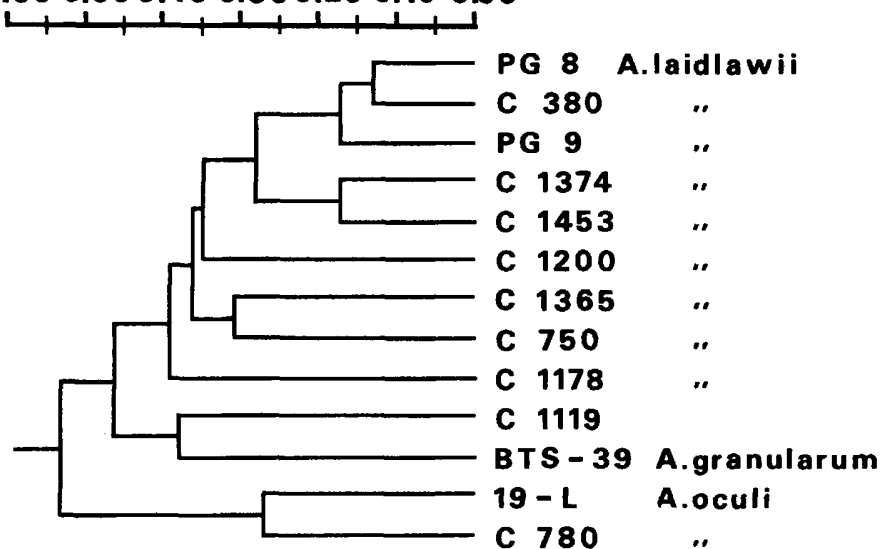

FIG. 1. Dendrogram based on a group average cluster analysis of Acholeplasma strains.

demonstrate the presence of malate dehydrogenase, the activity was very weak, possibly due to an unstable enzyme. Furthermore, we observed a positive effect of glucose in the media, in contrast to the findings of Lanham et al. (17).

To the best of our knowledge, the following 12 enzymes have not been reported previously in the genus Acholeplasma: alcohol dehydrogenase, aldolase, alkaline phosphatase, arginase, arginine deiminase, carbamyl phosphokinase, galactose dehydrogenase, galactose-6-phosphate dehydrogenase, glutamate dehydrogenase (nicotinamide adenine dinucleotide), glutamate dehydrogenase (nucleotide adenine dinucleotide phosphate), $\alpha$-glycerophosphate dehydrogenase, and xanthine dehydrogenase.

Inorganic pyrophosphatase activity was found in all three species examined, in contrast to the results of O'Brien et al. (24), who did not observe any inorganic pyrophosphatase activity in A. laidlawii. In our study inorganic pyrophosphatase, acid phosphatase, and alkaline phosphatase activities were demonstrated also in strains classified as phosphatase negative. These results indicate that isoenzyme analysis is a more sensitive test than the classical technique performed on solid media (1).

All acholeplasmas examined so far are arginine negative, which is in accord with our finding that none of the strains had ornithine transcarbamylase activity. On the other hand, arginine deiminase was demonstrated in two different electrophoretic forms. This observation is similar to the findings of Weickmann and Fahrney (36), who, by using protamine sulfate fractionation and diethylaminoethyl agarose chromatography, found that Mycoplasma arthritidis possesses two distinct forms of arginine deiminase. It seems that ornithine transcarbamylase might be the missing regulatory enzyme in the degradation of arginine, as both arginase and arginine deiminase were present in the strains of Acholeplasma which we studied.

Three different electromorphs of the isoenzyme aldolase were found in our material (Table 2). This is in agreement with the results obtained by Neimark $(21,22)$, who, by using the double immunodiffusion technique and antiserum against aldolase prepared from Streptococcus faecalis, demonstrated three different types of aldolase.

Dissimilarity coefficients (Table 3 ) and zymograms reveal both interspecific differences and intraspecific differences and can aid identification. As an example, we were not able to identify strain AMRC-C $\mathbf{3 8 0}$ by immunological methods, even by titration with $A$. laidlawii and $A$. oculi antisera diluted up to $1: 2,560$. However, the dissimilarity coefficient was 0.13 compared with strain $\mathrm{PG8}^{\mathrm{T}}$, indicating a close relationship to $A$. laidlawii at the species level. With regard to strain AMRC-C 1119, the growth inhibition tests were positive when all three antisera were used; however, the relationships of this strain could not be elucidated further, as the growth inhibition test is not suitable as a quantitative method. In the immunofluorescence test a titer of 160 was obtained when antiserum against $A$. laidlawii $\mathrm{PG8}^{\mathrm{T}}$ was used, but the serological identification was still uncertain, as the reactions were weak in the growth precipitation test (in some experiments, even absent). The dissimilarity coefficient compared with $A$. laidlawii was as high as 0.41 . The serological results and the dissimilarity coefficients may indicate that strain AMRC-C 1119 represents a fourth species. The zymograms of strain AMRC-C 1119 also show a pattern quite different from the patterns of the other strains, although the isoenzyme technique demonstrated some soluble, cytoplasmic proteins in common with the other strains. Perhaps these were antigens, which 
sometimes are evident in the growth precipitation test.

Our data indicate that isoenzyme analyses may aid identification, but because of strain variation within species may be even more useful in epidemiological investigations.

\section{ACKNOWLEDGMENTS}

We gratefully acknowledge E. A. Freundt for helpful discussions and comments and thank Andrew Clark and Folker Loeschcke for linguistic assistance.

\section{LITERATURE CITED}

1. Aluotto, B. B., R. G. Wittler, C. O. Williams, and J. E. Faber. 1970. Standardized bacteriologic techniques for the characterization of Mycoplasma species. Int. J. Syst. Bacteriol. 20:35-58.

2. Ashton, G. C., and A. W. H. Braden. 1961. Serum $\beta$ globulin polymorphism in mice. J. Exp. Biol. Med. Sci. 14:248-253.

3. Baur, E. W., and R. T. Schorr. 1969. Genetic polymorphism of tetrazolium oxidase in dogs. Science 166:15241525.

4. Black, F. T. 1973. Modifications of the growth inhibition test and its application to human T-mycoplasmas. Appl. Microbiol. 25:528-533

5. Brewer, G. J. 1970. An introduction to isoenzyme techniques. Academic Press, Inc., London.

6. Carter, R. 1973. Enzyme variation in Plasmodium berghei and Plasmodium vinckei. Parasitology 66:297-307.

7. Clayton, J. W., and D. N. Tretiak. 1972. Amine citrate buffers for $\mathrm{pH}$ control in starch gel electrophoresis. J. Fish. Res. Board Can. 29:1169-1172.

8. Erng, H., and M. M. Salth. 1980. The growth precipitation test as a diagnostic method for differentiation of $\mathrm{Myco}$ plasma and Acholeplasma species. Acta Vet. Scand. 21:469-481.

9. Fildes, R. A., and H. Harris. 1966. Genetically determined variation of adenylate kinase in man. Nature (London) 209:261-263.

10. Frydenberg, O., and V. Simonsen. 1973. Genetics of Zoarces population V. Amount of protein polymorphism and degree of genic heterozygosity. Hereditas 75:221-232.

11. Giblett, E. R. 1969. Genetic markers in human blood. Blackwell Scientific Publications, Oxford.

12. Godfrey, D. G., and V. Kilgour. 1976. Enzyme electrophoresis in characterizing the causative organism of Gambian trypanosomiasis. Trans. R. Soc. Trop. Med. Hyg. 70:219-224.

13. Harris, H., and D. A. Hopkinson. 1976. Handbook of enzyme electrophoresis in human genetics, $1 \mathrm{st}$ ed. NorthHolland Publishing Co., Amsterdam.

14. Heitmann, J., and H. Kirchhoff. 1978. Acholeplasma species differentiation with the growth precipitation test. Int. J. Syst. Bacteriol. 28:96-98.

15. Hjorth, J. P. 1971. Genetics of Zoarces populations. I. Three loci determining the phosphoglucomutase isoenzymes in brain tissue. Hereditas 69:233-242.

16. Kilgour, V., and D. G. Godfrey. 1973. Species-characteristic isoenzymes of two aminotransferases in trypanosomes. Nature (London) New Biol. 244:69-70.

17. Lanham, S. M., R. M. Lemcke, C. M. Scott, and J. M. Grendon. 1980. Isoenzymes in two species of Acholeplasma. J. Gen. Microbiol. 117:19-31.

18. Lee, G. Y., and G. E. Kenny. 1980. Electrophoretic and immunologic heterogeneity of the superoxide dismutases in the Acholeplasmataceae, p. 39. In Third Conference of the International Organization for Mycoplasmology, Custer, S.D.

19. Lemcke, R. M., S. M. Lanham, and C. M. Scott. 1978. Isoenzymes in two species of Acholeplasma, p. 175. In Second Conference of the International Organization for Mycoplasmology, Freiburg, West Germany.

20. Lynn, R. J., P. A. Guidici, E. J. Hollenweguer, and P. F. Smith. 1980. Humoral immune response of rabbits to acholeplasmal lipoglycans. Infect. Immun. 29:926-933.

21. Neimark, H. C. 1974. Implications of the phylogenetic relationship between Acholeplasma and lactic acid bacteria. Colloq. Inst. Natl. Santé Rech. Med. 33:71-78.

21. Neimark, H. C. 1974. Implications of the phylogenetic relationship between Acholeplasma and lactic acid bacteria. Collog. Inst. Natl. Santé Rech. Med. 33:71-78.

22. Neimark, H. C. 1979 . Phylogenetic relationships between mycoplasmas and other prokaryotes, p. 43-61. In M. F. Barile and S. Razin (ed.), The mycoplasmas, vol. 1. Cell biology. Academic Press, Inc., New York.

23. Nelson, R. L., S. Povey, D. A. Hopkinson, and H. Harris. 1977. Detection after electrophoresis of enzymes involved in ammonia metabolism using $\mathrm{L}$-glutamate dehydrogenase as a linking enzyme. Biochem. Genet. 15:1023-1035.

24. O'Brien, S. J., J. M. Simonsen, M. W. Grabowski, and M. F. Barile. 1981. Analysis of multiple isoenzyme expression among twenty-two species of Mycoplasma and Acholeplasma. J. Bacteriol. 146:222-232.

25. Rosendal, S., and F. T. Black. 1972. Direct and indirect immunofluorescence of unfixed and fixed mycoplasma colonies. Acta Pathol. Microbiol. Scand. Sect. B 80:615622.

26. Rosendal, S., and A. Valdivieso-Garcia. 1981. Enumeration of mycoplasmas after acridine orange staining. Appl. Environ. Microbiol. 41:1000-1002.

27. Schwartz, M. K., J. S. Nisselbaum, and O. Bodansky. 1963. Procedure for staining zones of activity of glutamic oxaloacetic transaminase following electrophoresis with starch gel. Am. J. Clin. Pathol. 40:103-106.

28. Selander, R. K., M. H. Smith, S. Y. Yang, and W. E. Johnson. 1971. Biochemical polymorphism and systematics in the genus Peromyscus. Variation in the old field mouse Peromyscus polionotus. Stud. Genet. 6:49-90.

29. Shaw, C. R. 1968. Starch gel recipes. Isosyme Bull. 1:2930 .

30. Simonsen, V., and O. Frydenberg. 1972. Genetics of Zoarces population. II. Three loci determining esterase isoenzymes in eye and brain tissue. Hereditas 70:235-242.

31. Simonsen, V., and M. M. Salih. 1982. Visualization of carbomate kinase in Acholeplasma species. Isosyme Bull. 15:137-138.

32. Smith, I. 1968. Chromatographic and electrophoretic techniques, 2nd ed., vol. 2. Zone electrophoresis. William Heinemann, London.

33. Sneath, P. H. A., and R. R. Sokal. 1973. Numerical taxonomy. W. H. Freeman, San Francisco.

34. Spencer, N., H. Harris, and D. A. Hopkinson. 1968. Adenosine deaminase polymorphism in man. Ann. Hum. Genet. 32:9-14.

35. Spencer, N., D. A. Hopkinson, and H. Harris. 1964. Phosphoglucomutase polymorphism in man. Nature (London) 204:742-745.

36. Weickmann, J. L., and D. E. Fahrney. 1977. Arginine deiminase from Mycoplasma arthritidis. J. Biol. Chem. 252:2615-2620.

37. Wellendorf, H., and V. Simonsen. 1978. A chemotaxonomic study in Picea with isoenzymes in the seed endosperm, p. 182-193. In Conference on the Biochemistry and Genetics of Forest Trees, Umeå, Sweden.

38. Yndgaard, C. F. 1972. Genetically determined electrophoretic variants of phosphoglucose isomerase and 6-phosphogluconate dehydrogenase in Zoarces viviparus L. Hereditas 71:151-154. 